fiber reinforced composite and bulk filling composites", Restor Dent Endod 2015,40 (4), pp.262-270.

2. Bonilla E D, Yasharb M, Caputo A A (2003), "Fracture toughness of nine flowable resin composites", The journal of prosthetic dentistry, 89, (3), pp.261-267.

3. Frater $M$, Forster $A$, Kereszturi $M$, Braunitzer G, Nagy K (2014), " In vitro fracture resistance of molar teeth restored with a short fibrereinforced composite material", Journal of dentistry, 42 (9), pp.1143-1150.

4. Fronza $B M$, Rueggeberg FA, Braga RR, Mogilevych B, Soares LES, Martin AA, Ambrosano Glaucia, Giannini M (2015), "Monomer conversion, microhardness, internal marginal adaptation, and shrinkage stress of bulk- fill resin composite", Dental Material, 31 (12), pp. 1542-1551.

5. Garoushi S, Sailynoja E, Vallittu PK, Lassila L (2013), "Physical properties and depth of cure of a new short fiber reinforced composite", Dental Materials, 29 (8), pp.835-841.

6. Garoushi S, Vallittu PK, Lassila LVJ (2011), "Fracture toughness, compressive strength and load-bearing capacity of short glass fiberreinforced composite resin", The Chinese Journal of dental research, 14 (1), pp.15-19.

7. Tezvergil A, Lassila LVj, Vallittu PK (2005), "The shear bond strength of bidirectional and random-oriented fiber-reinforced composite to tooth structure", Journal of Dentistry, 33 (6), pp.509-516.

\title{
NGHIÊN CỨU ĐộC TÍNH CẤP VÀ MộT Số TÁC DỤNG SINH HỌC CỦA CAO CHIẾT CÂY MÂM XÔI (RUBUS ALCEAEFOLIUS POIR., HỌ HOA HỒNG ROSACEAE) THU HÁI TẠI THÁI NGUYÊN
}

\section{TÓM TẮT}

Mục tiêu: Nghiên cứu đánh giá độc tính cấp, tác dụng chống viêm cấp và tác dụng lợi mật của cao chiết mâm xôi trên thực nghiệm. Đoối tượng và phương pháp: Xác định độc tính cấp đường uống; tác dụng chống viêm cấp trền mô hình gây phù bàn chân chuôt bằng carrageenan và tác dụng lợi mât trên chuột nhẳt trắng theo mô hình của ruddi. Kết quả: Cao chiết mâm xôi có $L D_{50}=12,75 \mathrm{~g} / \mathrm{kg}$. Cao chiết mâm xôi không thể hiện tác dụng chống viêm cấp trên mô hình gây phù bằng carrageenan ở chuột cống. Cao chiết mâm xôi ở cả 2 mức liều $1 \mathrm{~g} / \mathrm{kg}$ và $2 \mathrm{~g} / \mathrm{kg}$ đều thể hiện tác dụng lợi mật với tỷ lệ lượng dịch mật tăng tương ứng $32,79 \%$ và $41,30 \%$. Kết luận: Cao chiết mâm xôi có $\mathrm{LD}_{50} 12,75=\mathrm{g} / \mathrm{kg}$, có tác dụng lợi mật.

Tư khóa: Cao chiết mâm xôi, độc tính cấp, tác dụng lợi mật, tác dụng chống viêm cấp, Thái Nguyên.

\section{SUMMARY}

\section{STUDYING THE ACUTE TOXICITY AND SOME BIO-EFFECTS OF RUBUS ALCEAEFOLIUS POIR. EXTRACT, ROSACE IN THAI NGUYEN}

Objective: To evaluate the acute toxicity, acute anti-inflammatory effect and choleretic effect of Rubus alceaefolius Poir. extract in vivo. Objects and method: Determination of oral tocicity; acute anti-

*Trường Đại học Y Dược Thái Nguyên Chịu trách nhiệm chính: Nguyễn Văn Dũng Email: dung.dhdtn@gmail.com Ngày nhân bài: 17/2/2021 Ngày phản biện khoa học: 14/3/2021 Ngày duyệt bài: 7/4/2021
Nguyễn Văn Dũng*, Trần Ngọc Anh*, Phạm Thị Tuyết Nhung*, Bùi Thị Luyến*

inflammatory effect in model inflammation carrageenan-induced paw edema and choleretic effect in mice following the model of ruddi. Result: The Rubus Alceaefolius Poir. extract has $\mathrm{LD}_{50}=12.75 \mathrm{~g} / \mathrm{kg}$. The Rubus Alceaefolius Poir. extract didn't show acute anti-inflammatory effect in model inflammation carrageenan-induced paw edema in rats. The Rubus Alceaefolius Poir. extract at doses of $1.0 \mathrm{~g}$ and $2.0 \mathrm{~g} / \mathrm{kg}$ body weight significantly increased bile levels by $32.79 \%$ and $41.30 \%$ respectively. Conclusion: The Rubus Alceaefolius Poir. extract has $\mathrm{LD}_{50}=12.75 \mathrm{~g} / \mathrm{kg}$ and choleretic effect.

Keyword: Rubus Alceaefolius Poir. extract, acute toxicity, choleretic effect, acute anti-inflammatory, Thai Nguyen.

\section{I. ĐĂT VẤN ĐỀ}

Cây Mâm xôi (Rubus alceaefolius Poir., họ Hoa Hồng Rosaceae) được người dân sử dụng khá nhiều trong cuộc sống hằng ngày, quả thường được dùng để ăn, làm thuốc chữa đau thận hư, tinh ứ, liêt dương, đái són, hoạt tinh; cành lá già phơi khô, nấu nước uống thay chè giúp dễ tiêu hóa, lợi tiểu, chống viêm. Theo kết quả nghiên cứu của Nguyễn Văn Dũng và cộng sự (2019) cho thấy cao chiết mâm xôi có tác dụng hỗ trợ điều chỉnh rối loạn lipid máu [4], và nghiên cứu của Phạm Hồng Châu (2008) cho thấy cao chiết mâm xôi liều $4 \mathrm{~g}$ dược liêu/ $\mathrm{kg} / \mathrm{ngày}$ x 3 ngày (tương đương $0,4 \mathrm{~g}$ dược liệu/kg người) có tác dụng tăng tiết 44,07\% dịch mật [1], tiếp nối các kết quả nghiên cứu trên, chúng tôi tiến hành đề tài này với mục tiêu: (1) 
Đánh giá độc tính cấp của cao chiết mâm xôi. (2) Đánh giá tác dụng chống viêm cấp và tác dụng lợi mật của cao chiết mâm xôi trên thực nghiệm.

\section{II. ĐỐI TƯỢNG VÀ PHƯƠNG PHÁP NGHIÊN CỨU 2.1. Đối tượng}

*Nguyên liệu: Cành lá cây Mâm xôi (Rubus alceaefolius Poir.) được thu hái vào tháng 3 tại huyện Định Hóa, Tỉnh Thái Nguyên.

Sấy khô mâm xôi ở $50-60^{\circ} \mathrm{C}$ và xay thành bột thô. Bột dược liệu ngâm với ethanol 60\% tỷ lệ 1:10 (dược liệu: dung môi) ở nhiệt độ phòng trong 2 giờ sau đó chiết bằng phương pháp ngấm kiệt, tốc độ rút dịch chiết là $1 \mathrm{ml} / \mathrm{phút}$. Gộp dịch chiết và cất thu hồi dung môi dưới áp suất giảm rồi cho bốc hơi dung môi trên nồi cách thủy cho đến hết dung môi. Thu được cao đặc. Hiệu suất chiết là $9,7 \%$, độ ẩm cao là $15 \%$.

*Động vật thử nghiệm: Chuột cống trắng cả 2 giống, chủng Wistar, 150 - 180g Học viện Quân Y cung cấp. Chuột nhắt trắng chủng Swiss albino, 18 - 20g, Viện vệ sinh dịch tễ Trung ương cung cấp. Động vật được nuôi trong phòng thí nghiệm Bộ môn Dược lý, Trường Đại học Y Dược - Đại học Thái Nguyên 5 ngày trước khi nghiển cứu bằng thức ăn tiêu chuẩn do Viện vệ sinh Dịch tễ Trung ương cung cấp, uống nước tự do.

*Hóa chất và máy móc, thiết bị: Indomethacin (Dopharma), chophytol (Rosa Phytopharma), carrageenan (Sigma-Aldrich). Máy đô độ phù chân chuột Plethysmometer LE 7500 (Letica Scientific Instruments).

\subsection{Phương pháp}

2.2.1. Đánh giá thử độc tính cấp. Nghiên cứu tiến hành theo phương pháp Litchfield Wilcoxon [3], [6].

Chuột nhắt trắng chủng Swiss albino, giống cái, trọng lượng $20 \pm 2 \mathrm{~g}$, chuột được nhịn đói 12 giờ trước khi uống mấu thử, nước uống bình thường. Sau 12 giờ chuột được chia thành từng lô, mỗi lô 10 con:

Chuột uống chế phẩm thử với liều tăng dần. Chuột được cho ăn trở lại sau 2 giờ, nước uống bình thường. Theo dõi liên tục trong 72 giờ. Tìm được liều cao nhất chuột khổng chết và liều thấp nhất gây chết $100 \%$ số chuột. Tiếp tục theo dõi 7 ngày sau khi uống mẫu thử.

Chỉ tiêu theo dõi:

- Tình trạng chung của chuột: hoạt động tự nhiên, tư thế, màu sắc (mũi, tai, đuôi), lông, phân, nước tiểu...

- Tỉ lệ chuột chết trong vòng 72 giờ.

- Khi có chuột chết, mổ để quan sát đại thể các cơ quan phủ tạng. Nễu cần, làm thêm vi thể để xác định nguyên nhân.

- Căn cứ tỷ lệ chuột chết ở mỗi lô (nếu có) để tính $L D_{50}$.

2.2.2. Đánh giá tác dụng chống viêm cấp

Tác dụng chống viêm cấp được thử bằng mô hình gây phù bằng carrageenan theo Winter trên chuột cống trắng [5], [8]. Chuột được chia ngẫu nhiên thành 4 lô, mối lô 10 con:

Lô 1 (Chứng): uống nước muối sinh lý.

Lô 2 (Đối chiếu): uống thuốc đối chiều indomethacin $10 \mathrm{mg} / \mathrm{kg}$.

Lô 3 (Mâm xôi 1 ): uống cao chiết mâm xôi liều $0,5 \mathrm{~g} / \mathrm{kg}$.

Lô 4 (Mâm xôi 2): uống cao chiết mâm xôi liều $1,0 \mathrm{~g} / \mathrm{kg}$.

Chuột được uống dung môi hoặc mẫu thử hàng ngày vào một giờ nhất định, trong 7 ngày trước khi làm thực nghiệm. Thuốc đối chiếu chỉ dùng vào ngày làm thực nghiệm. Ngày thứ 7 đo thể tích bàn chân chuột sau phải sau khi uống thuốc. Ngay sau đó tiêm dung dịch carrageenan $1 \%$ trong nước muối sinh lý $(0,05 \mathrm{ml} /$ chuột $)$ vào gan bàn chân sau phải của chuột để gây viêm. Đo thể tích bàn chân sau phải của chuột vào thời điểm 2 giờ, 3 giờ, 5 giờ và 6 giờ sau khi tiêm carrageenan. Mức độ phù bàn chân sau phải chuột được tính theo công thức:

$$
\Delta \mathrm{V}(\%)=\frac{\mathrm{Vt}-\mathrm{VO}}{\mathrm{VO}} \times 100
$$

Trong đó: $\Delta \mathrm{V}$ là mức độ phù chân chuột tại thời điểm $\mathrm{t}$ giờ sau khi gây viêm.

V0 là thể tích chân chuột trước khi gây viêm.

Vt là thể tích chân chuột tại thời điểm $t$ giờ sau khi gây viêm.

Tác dụng ức chế phù (\%) của lô thử so với lô chứng được tính theo công thức:

$$
\mathrm{I}(\%)=\frac{\Delta \mathrm{Vc}-\Delta \mathrm{Vt}}{\Delta \mathrm{Vc}} \times 100
$$

Trong đó: I (\%) là phần trăm ức chế phù của lô thử so với lô chứng.

$\Delta V c$ là mức độ phù chân chuột trung bình ở lô chứng.

$\Delta V t$ là mức độ phù chân chuột trung bình ở lô thử.

2.2.3. Đánh giả tác dụng lợi mật trên thực nghiệm. Thử theo phương pháp Rudi [7].

Dùng chuột nhắt trắng, trọng lượng $22-25 \mathrm{~g}$, được chia ngẫu nhiên thành các lô:

- Lô 1 (Chứng): uống dd $\mathrm{NaCl}$ 0,9\%.

- Lô 2 (Đối chiếu): uống chophytol liều 320mg/kg.

- Lô 3 (Mâm xôi 1): uống cao chiết mâm xôi liều $1 \mathrm{~g} / \mathrm{kg}$.

- Lô 4 (Mâm xôi 2): uống cao chiết mâm xôi 
liều $2 \mathrm{~g} / \mathrm{kg}$.

Chuột uống thuốc hoặc mẫu thử hàng ngày vào một giờ nhất định trong 4 ngày trước khi làm thực nghiệm. Ngày thứ 5 , sau khi uống thuốc 30 phút, gây mê nhe cho từng chuột ở các lô bằng diethyl ether. Khi chuột đã mê, mổ bụng, thắt ống mật chủ, khâu vết mổ lại. Sau 30 phút, làm chết chuột bằng chloroform, mổ bụng, bóc tách túi mật và cân tươi ngay được khối lượng $\mathrm{m}_{1}(\mathrm{mg})$. Rạch túi mật, thấm tất cả dịch mật vào giấy lọc, cân ngay lại vỏ mật được khối lượng $\mathrm{m}_{2}(\mathrm{mg})$. Khối lượng mật trong từng túi mật là $\mathrm{m}(\mathrm{mg})=\mathrm{m}_{1}(\mathrm{mg})-\mathrm{m}_{2}(\mathrm{mg})$.

Quy lượng mật cho $100 \mathrm{~g}$ trọng lượng chuột.

So sánh khối lượng mật trung bình của lôt thử và lô chứng.

2.3. Xử lý số liệu. Kết quả được biểu diễn dưới dạng $X_{ \pm} S E$ ( $X$ : giá trị trung bình, $S E$ : sai số chuẩn). So sánh giá trị trung bình giữa các lô bằng phân tích one-way ANOVA, hậu kiểm để so sánh giữa thử với chứng (với thiết kế nghiên cứu từ 3 lô trở lên) hoặc dùng T-TEST ( với thiết kế nghiên cứu có 2 lô). Sự khác biệt được coi là có ý nghĩa thống kê khi $\mathrm{p}<0,05$.

\section{KẾT QUẢ NGHIÊN CỨU VÀ BÀN LUÂN}

3.1. Kêt quả độc tính cấp

Bảng 1. Kêt quả thử độc tính cấp của mẫu thử

\begin{tabular}{|c|c|c|c|}
\hline Lô & Số lượng & $\begin{array}{c}\text { Liều (g } \\
\text { cao/kg) }\end{array}$ & $\begin{array}{c}\text { Số chuột } \\
\text { chết }\end{array}$ \\
\hline 1 & 10 & 6 & 0 \\
\hline 2 & 10 & 7,5 & 1 \\
\hline 3 & 10 & 9 & 1 \\
\hline 4 & 10 & 10,5 & 2 \\
\hline 5 & 10 & 12 & 4 \\
\hline 6 & 10 & 13,5 & 6 \\
\hline 7 & 10 & 15 & 10 \\
\hline \multicolumn{2}{|c|}{ LD 5 tính theo Behrens[2] } & \multicolumn{2}{|c|}{$\mathbf{1 2 , 7 5} \pm \mathbf{0 , 6 2}$} \\
\hline
\end{tabular}

Nhận xét: Cao chiết mâm xôi có $L D_{50}=12,75$ $\pm 0,62 \mathrm{~g} / \mathrm{kg}$ (tương đương $111,7 \mathrm{~g}$ dược liệu $/ \mathrm{kg}$ ). Liều này cao gấp 140 - 280 lần so với liều trên người $(0,4-0,8 \mathrm{~g}$ dược liệu $/ \mathrm{kg})$. Như vậy có thể thấy cao chiết mâm xối có độ an toàn cao.

3.2. Tác dụng chống viêm cấp của cao chiết mâm xổi trên mô hình gây phù bằng carrageenan

Bảng 2. Ảnh hưởng của cao chiết mâm xôi lên mức độ phù chân chuột (\%)

\begin{tabular}{|c|c|c|c|c|c|c|}
\hline \multirow{2}{*}{ Lô } & \multirow{2}{*}{ Liều } & \multirow{2}{*}{$\mathbf{n}$} & \multicolumn{4}{|c|}{ Tỳ lệ phù bàn chân chuột (\%) } \\
\cline { 4 - 7 } & & & Sau 2 giờ & Sau 3 giờ & Sau 5 giờ & Sau 6 giờ \\
\hline Chứng & - & 10 & 25,3 & 37,6 & 42,1 & 40,6 \\
\hline Indomethacin & $10 \mathrm{mg} / \mathrm{kg}$ & 10 & $9,9^{* *}$ & $15,2^{* *}$ & $12,0 * *$ & $7,3^{* *}$ \\
\hline Mâm xôi 1 & $0,5 \mathrm{~g} / \mathrm{kg}$ & 10 & 24,5 & 40,1 & 38,3 & 36,4 \\
\hline Mâm xôi 2 & $1,0 \mathrm{~g} / \mathrm{kg}$ & 10 & 22,3 & 30,3 & 31,4 & 29,1 \\
\hline
\end{tabular}

**: $\mathrm{p}<0,01$ khi so sánh với lô chứng

Nhận xét: Indomethacin liều $10 \mathrm{mg} / \mathrm{kg}$ thể hiện tác dụng chống viêm cấp tốt tại $2 \mathrm{~h}, 3 \mathrm{~h}, 5 \mathrm{~h}$ và $6 \mathrm{~h}$ sau khi gây viêm $(p<0,05)$. Cao chiết mâm xôi liều $0,5 \mathrm{~g}$ cao $/ \mathrm{kg}$ và liều $1,0 \mathrm{~g}$ cao $/ \mathrm{kg}$ không có tác dụng ức chế phù bàn chân ở các thời điểm $2 h, 3 h, 5 h, 6 h$ sau khi gây viêm $(p>0,05)$.

\subsection{Kết quả tác dụng lợi mật}

\begin{tabular}{|c|c|c|c|c|}
\hline \multirow[b]{2}{*}{ STT } & \multicolumn{4}{|c|}{ Lượng dịch mật/100g chuột (mg) } \\
\hline & Lô chứng & $\begin{array}{c}\text { Lô đối chiếu } \\
\text { (chophytol } 320 \mathrm{mg} / \mathrm{kg} \text { ) }\end{array}$ & $\begin{array}{c}\text { Mâm xôi 1 } \\
(1 \mathrm{~g} / \mathrm{kg})\end{array}$ & $\begin{array}{c}\text { Mâm xôi } 2 \\
(2 \mathrm{~g} / \mathrm{kg})\end{array}$ \\
\hline 1 & 0,081 & 0,098 & 0,096 & 0,098 \\
\hline 2 & 0,051 & 0,076 & 0,093 & 0,088 \\
\hline 3 & 0,048 & 0,096 & 0,059 & 0,065 \\
\hline 4 & 0,082 & 0,140 & 0,092 & 0,105 \\
\hline 5 & 0,051 & 0,087 & 0,071 & 0,062 \\
\hline 6 & 0,053 & 0,110 & 0,077 & 0,091 \\
\hline 7 & 0,043 & 0,087 & 0,088 & 0,092 \\
\hline 8 & 0,085 & 0,091 & 0,086 & 0,097 \\
\hline 9 & 0,058 & 0,100 & 0,071 & 0,082 \\
\hline $\bar{X} \pm$ SE & $0,061 \pm 0,002$ & $0,098 \pm 0,002$ & $0,081 \pm 0,001$ & $0,087 \pm 0,001$ \\
\hline $\mathrm{p}$ & - & 0,0004 & 0,010 & 0,003 \\
\hline Độ lợi mật (\%) & - & 60,32 & 32,79 & 41,30 \\
\hline
\end{tabular}

Nhận xét: Cao chiết mâm xôi liều $1 \mathrm{~g}$ cao $/ \mathrm{kg} / \mathrm{ngày}$ uống trong 5 ngày có tác dụng làm tăng lượng dịch mật $(0,081 \pm 0,001 \mathrm{mg})$ so với lô chứng $(0,061 \pm 0,002 \mathrm{mg})$, làm tăng $32,79 \%$

dịch mật (tính theo khối lượng). Sự khác biệt này có ý nghĩa thống kê $(p<0,05)$.

Cao chiết mâm xôi liều $2 \mathrm{~g}$ cao $/ \mathrm{kg} / \mathrm{ngày}$ uống trong 5 ngày có tác dụng làm tăng lượng dịch 
mật $(0,087 \pm 0,001 \mathrm{mg})$ so với lô chứng $(0,061 \pm$ $0,002 \mathrm{mg}$ ), làm tăng $41,30 \%$ dịch mật (tính theo khối lượng). Sự khác biệt này có ý nghĩa thống kê $(p<0,05)$.

Như vây sơ bô kết luân cao chiết mâm xôi có tác dụng lợi mật trên mô hình thực nghiệm.

\section{KẾT LUÂN}

Cao chiết mâm xôi có $L D_{50}=\mathrm{g} / \mathrm{kg}$, cao gấp lần liều trên người, chứng tỏ mẫu thử có độ an toàn cao khi sử dung.

Cao chiết mâm xôi ở cả 2 mức liều $0,5 \mathrm{~g} / \mathrm{kg}$ và $1 \mathrm{~g} / \mathrm{kg}$ đều không thể hiện tác dụng chống viêm cấp trên mô hình gây phù bằng carrageenan ở chuột cống.

Cao chiết mâm xôi ở cả 2 mức liều $1 \mathrm{~g} / \mathrm{kg}$ và $2 \mathrm{~g} / \mathrm{kg}$ đều thể hiện tác dụng lợi mật với tỷ lệ lượng dịch mật tăng tương ứng $32,79 \%$ và 41,30\% trên chuột nhắt trắng.

\section{KIẾN NGH!}

Chúng tôi bước đầu đã chứng minh cao chiết cây mâm xôi thu hái tại Thái Nguyên có tác dụng làm tăng tiết mật trên mô hình thực nghiệm và độ an toàn với $L_{50}=12,75 \mathrm{~g} / \mathrm{kg}$. Với mong muốn đưa sản phẩm này vào ứng dung thực tiễn, chúng tôi kiến nghị được tiếp tục nghiển cứu về độc tính bán trường diễn và một số tác dụng bảo vệ gan.

\section{TÀI LIÊU THAM KHẢO}

1. Phạm Hồng Châu (2008), Nghiên cứu thành phần hóa hoc và môt số tác dung sinh hoc của dược liệu mẩm xôi, Khóa luận tốt nghiệm dược sỹ Trường Đai hoc Dước Hà Nôi.

2. Cục khoả học công nghề và đào tạo (2015), Hướng dẩn thử nghiếm tiền lâm sàng và lâm sàng thuốc đông $y$, thuốc từ dược liệu, ban hành kèm theo quyêt định 141/QĐ-K2E்T.

3. Đố Trung Đàm (1996), Phương pháp nghiên cứu độc tính cấp của thuốc, NXB Y học, Hà Nội.

4. Nguyễn Văn Dũng, Trân Ngoc Anh và cs (2019), "Tác dụng điêu chỉnh rối loạn lipid máu trên thực nghiệm của cao chiết cẩy mâm xôi (Rubus alceaefolius Poir, ho Hoa hồng Rosaceae) thu hái tại Thái Nguyên", Tạp chí Y học Việt Nam, 483(2), tr. 178 - 182.

5. Viện Dược liệu (2006), Phương pháp nghiên cứu tác dưng dước lý của thuốc từ thảo dược, NX Khoa hoc và Kỹ thuât.

6. Litfield, Wilcoxon (1948), "A simplified method of evaluating dose-effect experiment", J. Pharmacol Exp. Ther, pp. 99 - 113.

7. Rudi R. V. (1977), Pharm and Toxicology, vol 4 pp. 11-16.

8. Winter C.A., Risley E.A., et al. (1962), "Carrageenan-induced edema in hind paw of the rat as an assay for anti-onflammatory drugs", Proc. Soc. Exp. Biol, 11, pp. 544 - 574.

\section{ĐẶC ĐIỂM HÌNH THÁI TINH TRÙNG ĐƯợC NHUộM BẰNG PAPANICOLAOU, GIEMSA VÀ EOSIN}

\section{TÓM TẮT}

Mục tiêu: So sánh đăc điểm hình thái tinh trùng được nhuộm bằng ba phương pháp Papanicolaou, Giemsa, Eosin. Đối tượng và phương pháp nghiên cứu: Mô tả cắt ngang đặc điểm hình thái tinh trùng ở 30 mấu tinh dịch có thông số trong giới hạn bình thường. Mối mấu tinh trùng đươc nhuộm bằng 3 phương pháp Papanicolaou, Giemsa, Eosin. Tiêu bản được quan sát dưới kính hiển vi quang học, hình ảnh được chụp và đo kích thước tinh trùng bằng phần mềm Infinity Analyze. Kết quả: Các đặc điểm chi tiết hình thái bình thường và bất thường của tinh trùng được nhuộm bằng 3 phương pháp không có sự khác biệt có ý nghĩa thông kê. Kích thước đầu tinh trùng nhuộm bằng Eosin lớn hơn so với nhuôm bằng Papanicolaou, Giemsa, sự khác biệt có ý nghĩa thống

*Trường Đại học Y Dược Thái Nguyên

Chịu trách nhiệm chính: Phạm Minh Huệ

Email: phamminhhuebs@gmail.com

Ngày nhận bài: 17/2/2021

Ngày phản biên khoa hoc: 22/3/2021

Ngày duyệt bài: $7 / 4 / 2021$
Phạm Minh Huệ*

kê. Tỷ lệ chiều dài/rônng và đô dài đuôi không khác biệt giữa các phương pháp nhuộm. Phần đâuu và tú cực đâu quan sát rất rõ ở nhuộm Papanicolaou, Giemsa. Phân đuôi và đoạn trung gian quan sát rất rõ ở nhuộm Papanicolaou. Kết luận: Phương pháp nhuôm Papanicolaou phù hợp trong nghiên cứu đánh giá hình thái tinh trùng. Nhuôm Giemsa và Eosin có thể áp dụng trong xét nghiệm tinh dịch đồ thường quy.

Tư khóa: Hình thái tinh trùng, nhuộm tinh trùng, Papanicolaou, Giemsa, Eosin.

\section{SUMMARY}

\section{THE CHARACTER OF SPERM MORPHOLOGY IN PAPANICOLAOU, GIEMSA, AND EOSIN METHODS}

Objectives: Comparison of Morphological sperm stained by Papanicolaou, Giemsa, Eosin methods. Material and methods: A descriptive cross-sectional study of 30 semen samples with normal limited parameters. Each sample stained by Papanicolaou, Giemsa, Eosin methods. The slides were observed under the light microscope, the spermatozoa images were captured and measured in size using Infinity Analyze software. Results: The normal and abnormal 